\title{
Bacteriological Profile of Acute Respiratory Infections in Children: About a Prospective Study at the Albert Royer Hospital in Dakar
}

\author{
Guillaye Diagne $^{1 *}$, A. Kane ${ }^{1}$, A. Mbaye ${ }^{1}$, A. M. Coundoul'1, S. Sow ${ }^{1}$, K. Bop ${ }^{1}$, A. Sow ${ }^{2}$, I. D. Ba1, \\ 0. Ndiaye ${ }^{1}$ \\ ${ }^{1}$ Albert Royer Children's Hospital of Dakar, Dakar, Senegal \\ ${ }^{2}$ Pediatrics Department of the Abass NDAO Hospital Center, Dakar, Senegal \\ Email: ^diagneguilso29@gmail.com, haroyer@refer.sn, amadousoow@hotmail.com
}

How to cite this paper: Diagne, G., Kane, A., Mbaye, A., Coundoul, A.M., Sow, S., Bop, K., Sow, A., Ba, I.D. and Ndiaye, O. (2021) Bacteriological Profile of Acute Respiratory Infections in Children: About a Prospective Study at the Albert Royer Hospital in Dakar. Open Journal of Pediatrics, 11, 71-77.

https://doi.org/10.4236/ojped.2021.111007

Received: December 24, 2020

Accepted: March 5, 2021

Published: March 8, 2021

Copyright $\odot 2021$ by author(s) and Scientific Research Publishing Inc. This work is licensed under the Creative Commons Attribution International License (CC BY 4.0).

http://creativecommons.org/licenses/by/4.0/ (c) (i) Open Access

\begin{abstract}
Introduction: Acute Respiratory Infections (ARI) is a global public health priority. It is the leading cause of childhood morbidity and mortality, especially in developing countries. The main objective of this work was to look mainly at the bacteriological aspects of ARI in children in Senegalese hospitals. Methodology: We have been conducted a prospective descriptive monocentric study over a period of one year (from July 1, 2017 to June 30, 2018) at the Albert Royer National child hospital in Dakar. A multiplex PCR (protein chain reaction) has been performed on nasopharyngeal swabs taken from all patients. This technique (viral RNA transcribed into DNA, then the DNA of the different pathogens is simultaneously amplified in the same tube by PCR Fast-tract ${ }^{\oplus}$, multiplex). Results: During the study period, 109 patients were included. The hospital prevalence of acute respiratory infections was 3.7\%. The mean age was 23.7 months with extremes between 1 month and 144 months. Peaks of consultations were found in the months of August, March and April with 22\%, $15.6 \%$ and $12.8 \%$ respectively. Fever, respiratory distress and pulmonary condensation syndrome were the main signs found in our patients. Bacteriology was positive in $82.6 \%$ of samples and the most frequently found bacteria were Streptococcus pneumoniae in 38.5\%, Haemophilus influenza b in $32.1 \%$ and Moraxella catarrhalis in $25.7 \%$. Pneumonia was the main diagnosis, found in 61 cases, a prevalence of 59.9\%. The average length of hospitalization was 10 days. Lethality was $1.8 \%$ or 2 cases. Conclusion: Acute Respiratory Infections in children still remains a public health problem in developing countries; children under 5 years of age are the most affected hence the need to strengthen ARI control programs. The identification of germs is indispensable in treatment and epidemiological surveillance in our regions.
\end{abstract}




\section{Keywords}

Acute Respiratory Infection, Child, Bacteria, Dakar

\section{Introduction}

Acute Respiratory Infections (ARI) is a public health priority worldwide. It is the leading cause of morbidity and mortality in children under five (05) years of age, especially in developing countries, behind neonatal causes [1]. The World Health Organization (WHO) estimates the number of deaths due to pneumonia among children under five (05) years of age at more than two (02) million each year. The majority of deaths occur in low-income countries [2] [3]. The etiologies are multiples (bacteria, viruses, parasites or fungi). In this context, bacterial caused are very frequent.

The diagnosis of bronchopulmonary infections requires an extremely rigorous semiological, clinical and radiological analysis.

In Senegal, few studies have been focused on the bacteriological profile of acute respiratory infections in children. This one is one of the first studies on the subject.

The main objective of this study is to identify the bacteria responsible for acute respiratory infections in children.

The secondary objective is to describe the epidemiological, diagnostic and evolutionary aspects of ARI in children hospitalized at the Albert Royer Hospital in Dakar.

\section{Methodology}

It was a prospective descriptive single-center study over a period of one year (from July 1, 2017 to June 30, 2018), conducted at the Albert Royer National Children's Hospital in Dakar in the department ofpneumopediatric.

An authorization has been requested from each parent before the inclusion of their children.

We included children aged 0 to 15 years old hospitalized for respiratory symptoms associated with fever or a history of fever evolving for less than ten (10) days who were given a nasopharyngeal swab to allow the search for germs using the multiplex PCR technique (viral RNA transcribed into DNA, then the DNA of the different pathogens is simultaneously amplified in the same tube by PCR Fast-tract ${ }^{\oplus}$, multiplex).

Acute respiratory infection has been defined by the presence of fever associated with respiratory symptoms evolving less than ten (10) days prior to admission.

All incomplete records and non-compliant specimens were excluded from the study.

The parameters studied were epidemiological, clinical, paraclinical, therapeu- 
tic and progressive. Data have been collected and analyzed using Epi Info version 7.2 software. A p $<0.05$ is considered significant.

\section{Results}

During the study period 109 patients were included. The hospital prevalence of acute respiratory infections was $3.7 \%$. The sex ratio was 1.8 . The mean age of the children was 23.7 months. Of these children, $55.1 \%$ were from the urban area. Peaks of consultations were found during the months of August, March and April with $22 \%, 15.6 \%$ and $12.8 \%$ respectively. The entire study population was fully vaccinated according to Senegal's current Expanded Program on Immunization (EPI). The grounds and co-morbidities found were malnutrition in 3 cases, heart disease in 4 cases, sickle cell disease in 1 case and asthma in 5 cases. The reasons for consulting our patients were fever in $94.5 \%$ of cases, cough in $94.5 \%$ and rhinitis in $52.3 \%$ of cases as shown in Figure 1.

The blood test performed in all the children showed hyperleukocytosis predominantly in $73.4 \%$ of the population. Thrombocytopenia has been found in 7 children. The C-reactive protein was positive in $97.3 \%$ of cases with an average of $96 \mathrm{mg} / \mathrm{l}$.

Bacteriological examination was positive in $82.6 \%$ of the samples. Single germ samples were predominant with $47.1 \%$. Figure 2 shows the number of germs per sample.

The bacteria most frequently found in the samples were respectively Streptococcus pneumoniae in 38.5\%, Haemophilus influenza b in $32.1 \%$ and Moraxella catarrhalis in $25.7 \%$. Table 1 presents the prevalence of bacteria found in the different samples. The positive diagnoses are summarized in Table 2.

Antibiotic therapy has been administered to $58.7 \%$ of the study population (64 children), corticosteroid therapy to $39.5 \%$ and oxygen therapy to $34.9 \%$. The average length of hospitalization was 10 days; the main complications noted were atelectasis in 04 cases, pleurisy in 12 cases, and septic shock in 2 cases. The evolution was favorable in $98.2 \%$. Lethality was $1.8 \%$.

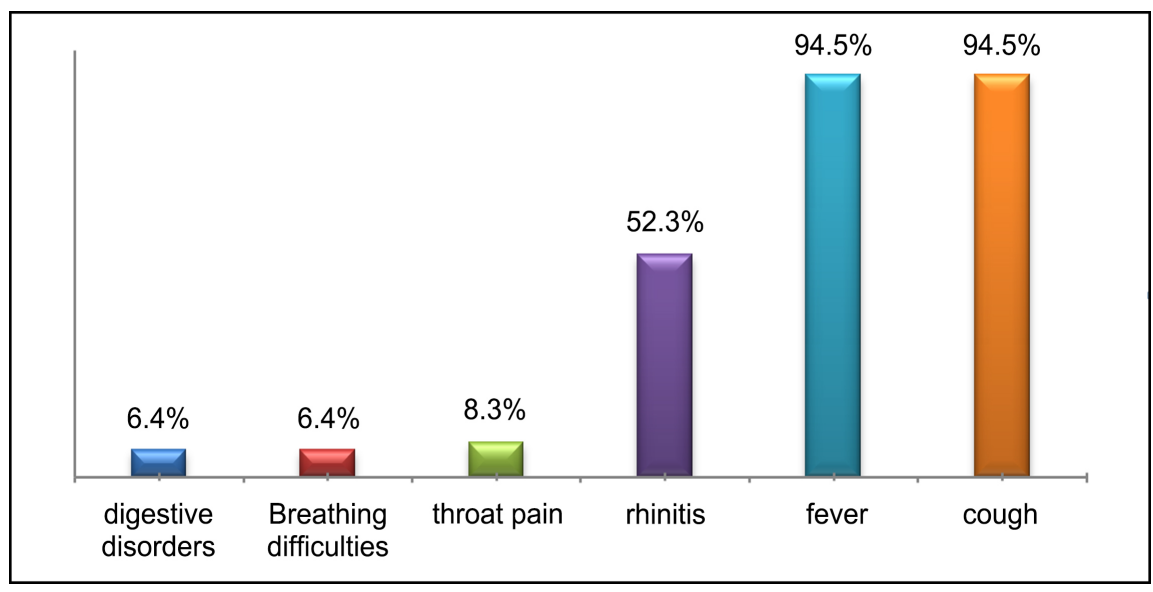

Figure 1. Distribution of study population by reasons for consulting $\mathrm{N}=109$. 


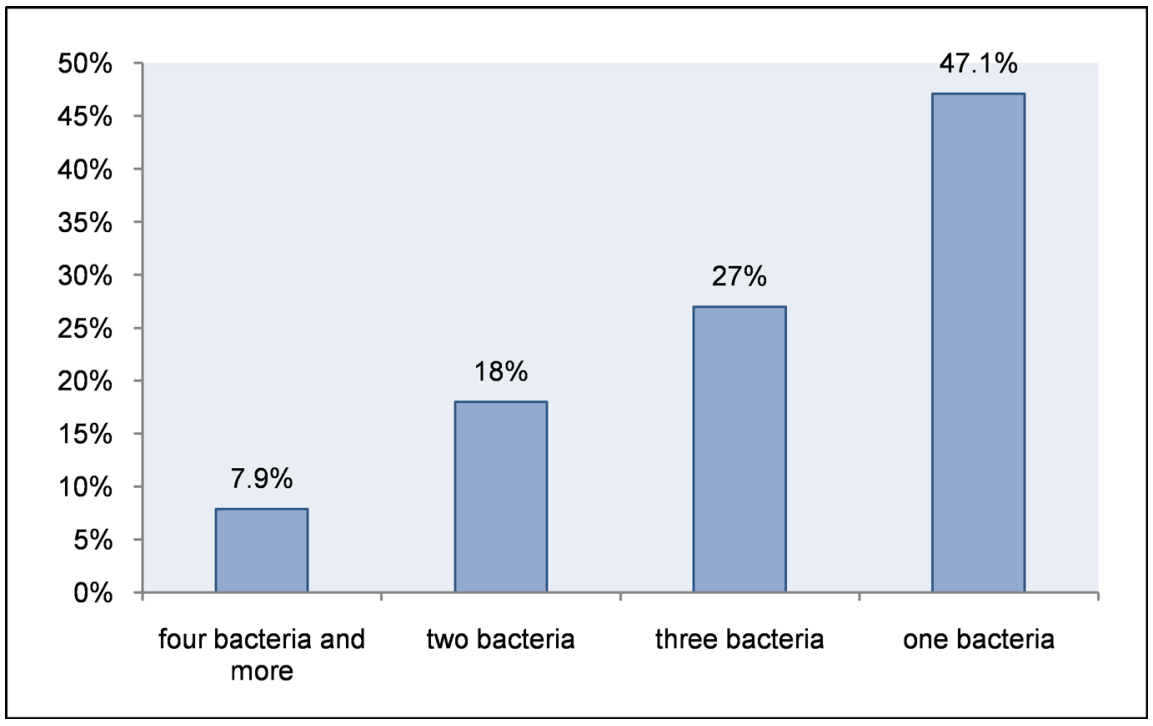

Figure 2. Distribution according to the number of bacteria present per sample.

Table 1. Distribution according to the bacteria found in the samples.

\begin{tabular}{ccc}
\hline Bacteriafound in samples & Number (n) & Percentage (\%) \\
\hline S. pneumoniae & 42 & 38.5 \\
H. influenzae $b$ & 35 & 32.1 \\
M. catarrhalis & 28 & 25.7 \\
S. aureus & 27 & 24.8 \\
K. pneumoniae & 27 & 24.8 \\
Legionella pneumophila & 6 & 5.5 \\
M. pneumoniae & 3 & 2.8 \\
Bordetella pertussis & 2 & 1.8 \\
\hline
\end{tabular}

Table 2. Breakdown by positive diagnosis.

\begin{tabular}{ccc}
\hline Diagnosis & Number(n) & Percentage (\%) \\
\hline Pneumonia & 61 & 55.9 \\
Acute Bronchiolite & 33 & 30.4 \\
Pleuresie & 12 & 11.0 \\
Pertussis & 2 & 1.8 \\
Laryntracheobonchitis & 1 & 0.9 \\
All & 109 & 100.0 \\
\hline
\end{tabular}

\section{Discussion}

The prevalence found in this study is relatively low. Higher prevalenceis found in other countries in sub-Saharan Africa. In the Democratic Republic of Congo, Ngombé [4] in 2014 found a hospital prevalence of $26.11 \%$ of high and low ARI. In the Congo, Moyen [5] reported 19.8\%. In the West, in Brazil in 2008, Prietsch 
et al. [6] reported a community prevalence of $23.9 \%$ of low ARI in children under 5 years old. In North America, an incidence of 30 - 45 cases per 1000 in children under 05 years old and 6 - 12 cases per 1000 in children over 5 years of age [7]. The average age of our children was 23.7 months. A stackable mean age has been described by other authors [8].

Acute respiratory infections can occur at any age. Young children, especially those under 5 years, are most vulnerable [7]. This justifies the fact that most of the world's programs to combat child morbidity and mortality focus on this age group. Vulnerability in this age group is thought to be related to the immaturity of their immune system and the nasopharyngeal carriage of certain germs [9]. In this study, children under 5 years of age represented $88 \%$ of the total number of children.

The sex ratio 1.8 has been observed largely in favor of boys. This male predominance is described by most authors both in Senegal and worldwide. Krishnan, in 2012 in India found that the frequency of hospitalization for ARI in boys was 2.4 times higher than in girls [10].

Our study shows an unequal distribution between months of hospitalization with peaks of ARI occurrence during the months of March and April, corresponding to the transition period between cool and hot weather. This climate favors ENT infections, which weakens the respiratory mucosa and facilitates the spread of germs.

In developed countries, a seasonal distribution of ARI is noted, especially in autumn and winter [11] [12].

The majority of our children came from the disadvantaged areas of Dakar characterized by low socioeconomic status, promiscuity and high air pollution, often with poorly ventilated habitats. These different elements are factors in the occurrence of ARIs.

All our patients had benefited from a nasopharyngeal swab studied using the multiplex PCR technique. This technique (viral RNA transcribed into DNA, then the DNA of the different pathogens is simultaneously amplified in the same tube by PCR Fast-tract ${ }^{\oplus}$, multiplex) allowed us to isolate bacteria.

Streptococcus pneumonia was the first germ responsible for ARI in children in Senegal [13]. But these studies were not based on the use of multiplex PCR.

In our series, Streptococcus pneumoniae was the first bacterium isolated, followed by Haemophilus influenza $b$ and Moraxella catarrhalis with 38.5\%, 32.1\% and $25.7 \%$ respectively. Staphylococcus aureus was found in $24.8 \%$ of cases.

In Switzerland, Katia Jaton [14] found pneumococcus (Streptococcus pneumoniae) and Haemophilus influenzae as germs in her study on the microbiological diagnosis of pneumonia [14].

These cases of Haemophilus influenzae could be asymptomatic carriers because all our patients had good vaccination coverage and the technique used did not allow distinguishing a pathogenic germ from a carrier-related germ.

The death has been found in two (2) children, and this can be explained by the 
fact that these children presented a severe sepsis with multivisceral failure.

In Africa, the death rate is lower than that of Moyen el al in Congo Brazzaville (16.25\%) and Bakonde (7.5\%) in Togo [15].

This study has limitations. Firstly, the sample is not large enough to allow overall conclusions to be drawn, hence the need to conduct other larger studies with many more patients. On the other hand, the results of nasopharyngeal samples do not always reflect the germ responsible for pneumonia in children, hence the importance of coupling it with central samples in order to make the correlation. Other studies will be made taking into account all its limitations in order to be able to draw definitive conclusions

\section{Conclusions}

Acute Respiratory Infections (ARI) in children are an important factor in morbidity and mortality in children under five years of age in Senegal and worldwide, despite WHO guidelines for the management of ARI in children.

This study is a first and allowed us to know the germs responsible for ARI in children hospitalized in our structure.

\section{Conflicts of Interest}

The authors declare no conflicts of interest regarding the publication of this paper.

\section{References}

[1] Rasmussen, Z., Pio, A. and Enarson, P. (2000) Case Management of Childhood Pneumonia in Developing Countries: Recent Relevant Research and Current Initiatives. International Journal of Tuberculosis and Lung Disease, 4, 807-826.

[2] Leowski, J. (1986) Mortality from Acute Respiratory Infections in Children under 5 Years of Age: Global Estimates. World Health Statistics Quarterly, 39, 138-144.

[3] United Nations Children's Fund, World Health Organization, World Bank and United Nations Department of Economic and Social Affairs Population Division (2014) Levels and Trends in Child Mortality 2014. United Nations Inter-Agency Group for Child Mortality Estimate. United Nations Children's Fund, World Health Organization, World Bank, United Nations Population Division, New York.

[4] Ngombe, L.K., Mbombo, D., Kameya, N., Malingo, A.A., Kayomb, N., Ngolomba, J.N., et al. (2014) Acute Respiratory Infection and Nutritional Status in Children Aged 0-5: Case of University Clinics in Lubumbashi, Democratic Republic of Congo. Pan African Medical Journal, 19, 393.

[5] Moyen, E., Kambourou, J., Okoko, A.R., Nguelongo, L., Bomelefa-Bomel, V., Nkounkou, K., et al. (2018) Child Acute Lower Respiratory Tract Infection in Pediatrics Intensive Care Unit at University Hospital of Brazzaville (Congo). Open Journal of Pediatrics, 8, 32-41. https://doi.org/10.4236/ojped.2018.81005

[6] Prietsch, S.O.M., Fischer, G.B., César, J.A., Lempek, B.S., Barbosa Jr., L.V., Zogbi, L., et al. (2008)Acute Lower Respiratory Illness in Under-Five Children in Rio Grande, Rio Grande do Sul State, Brazil: Prevalence and Risk Factors. Cadernos de Saúde Pública, 24, 1429-1438. http://dx.doi.org/10.1590/S0102-311X2008000600023

[7] Stein, R.T. and Marostica, P.J. (2007) Community-Acquired Pneumonia: A Review 
and Recent Advances. Pediatric Pulmonology, 42, 1095-103.

https://doi.org/10.1002/ppul.20652

[8] O’Leary, F., Hayen, A., Lockie, F. and Peat, J. (2015) Defining Normal Ranges and Percentiles for Heart and Respiratory Rates in Infants and Children: A Cross Sectional Study of Patients Attending an Australian Tertiary Hospital Pediatric Emergency Department. Archives of Disease in Childhood, 100, 733-737. http://dx.doi.org/10.1136/archdischild-2014-307401

[9] Leung, A.K.C., Wong, A.H.C. and Hon, K.L. (2018) Community-Acquired Pneumonia in Children. Recent Patents on Inflammation \& Allergy Drug Discovery, 12, 136-144. https://doi.org/10.2174/1872213X12666180621163821

[10] Krishnan, A., Amarchand, R., Gupta, V., Lafond, K.E., Suliankatchi, R.A., Saha, S., et al. (2015) Epidemiology of Acute Respiratory Infections in Children-Preliminary Results of a Cohort in a Rural North Indian Community. BMC Infectious Diseases, 15, Article No. 462. https://doi.org/10.1186/s12879-015-1188-1

[11] Boyd, K. (2017) Back to the Basics: Community-Acquired Pneumonia in Children. Pediatric Annals, 46, e257-e261. https://doi.org/10.3928/19382359-20170616-01

[12] Oliveira, T.G., Moraes, J.S.B., Moreira, F.T., Arrelaro, R.C., Ricardi, V.A., Bertagnon, J.R., et al. (2011) Evaluation of Hospitalization of Children Aged 0 to 5 Years Admitted for Respiratory Infections at a Large Hospital. Einstein (São Paulo), 9, 514-517. http://dx.doi.org/10.1590/s1679-45082011ao1908

[13] Cissé, M.F., Breukelman, J.G., Bâ, M., Diop, M.B., Faye, P.C., Mhlanga, B., et al. (2010)The Elimination of Haemophilus influenzae Type B Meningitis Following Conjugate Vaccine Introduction in Senegal. The Pediatric Infectious Disease Journal, 29, 499-503. https://doi.org/10.1097/INF.0b013e3181ccb0a0

[14] Jaton, K., Schrenzel, J. and Greub, G. (2014) Microbiological Diagnosis of Pneumonia. Revue Médicale Suisse, 10, 2126-2129.

[15] Bakonde, B., Tatagan, K., Kessie, K., et al. (1998) Hospital Epidemiology of Acute Low Respiratory Infections in Togolese Infants and Children. Medicine of Black Africa, 45, 435-439. 